\title{
Effect of humic acid and naphthalene acetic acid on vegetative growth and fruit quality of tomato plants Lycopersicon esculentum
}

\author{
Ahmad A. Suliman ${ }^{1,2 *}$ Alexandr G. Abramov², Anna A. Shalamova², \\ Antar M. Badran ${ }^{3,4}$ \\ ${ }^{1}$ National Research Centre, Giza, Egypt \\ ${ }^{2}$ Kazan State Agrarian University, Kazan, Republic of Tatarstan, Russian Federation \\ ${ }^{3}$ Desert Research Center, Cairo, Egypt \\ ${ }^{4}$ Peoples' Friendship University of Russia, Moscow, Russian Federation \\ *Corresponding author: a_elsagheer2006@yahoo.com
}

\begin{abstract}
The study aimed to improve fruit set and plant performance to increase tomato productivity by studying the effect of plant growth regulators on tomato plants (Lycopersicon esculentum). A specific experiment has been carried out to study the effect of plant growth regulators Hemo bles (humic acid, 850g/kg) at applied doses (250, 500 and 700 ppm) and Magictone (naphthalene acetic acid and naphthalene acetamide, 5...12.5 $\mathrm{g} / \mathrm{kg}$ ) at applied doses (250, 500 and $700 \mathrm{ppm}$ ) on growth and physiological characteristics of tomato plants (Big Beef F1). The experimental design was a Complete Randomized Blocks Design. Both Hemo bles and Magictone were applied three times (spraying on plants at 30 days after planting (DAP), 60 DAP and 90 DAP). The obtained results showed that, applying Ener-850 humic acid caused the highest significant plant height (264.6 $\mathrm{cm})$, number of leaves/plant (45), stem diameter $(1.9 \mathrm{~cm})$ and fruit weight $(137 \mathrm{~g})$ during the two seasons. In addition, applying Magictone resulted in the highest significant flower number (48.1), fruit number (35.1) and flower clusters number in the plant (13.6). Additionally, humic acid significantly increased dry weight (75.1 g) of arial parts with improving of tomato fruit quality via enhancing the concentrations of ascorbic acid, level of vitamin $\mathrm{C}$ and carotenoid content. The results were analyzed using one-way analysis of variance (ANOVA) followed by Tukey's HSD test with $\alpha=0.05$ with the help of MINITAB (v. 19.0) program.
\end{abstract}

Key words: tomato, humic acid, naphthalene acetic acid, plant growth regulators, ascorbic acid

\section{Article history:}

Received: 18 December 2019. Accepted: 13 January 2020

\section{For citation:}

Suliman AA, Abramov AG, Shalamova AA, Badran AM. Effect of humic acid and naphthalene acetic acid on vegetative growth and fruit quality of tomato plants Lycopersicon esculentum. RUDN Journal of Agronomy and Animal Industries. 2020; 15(1): 30-39. doi: 10.22363/2312-797X-2020-15-1-30-39

(c) Suliman A.A., Abramov A.G., Shalamova A.A., Badran A.M., 2019.

This work is licensed under a Creative Commons Attribution 4.0 International License 


\section{Introduction}

Tomato Solanum lycopersicum belongs to the family Solanaceae. Tomato is the most important vegetable crop in both open field and greenhouses [1]. In view of the rapid increase in population growth and the increase in consumption of foodstuffs, including the tomato crop, scientific studies have begun on the methods available to increase production, including the study of the influence of growth regulators on agricultural production. Farmers often apply some chemical substances which have similar structure and activity with endogenous plant hormone called exogenous Plant Growth Regulators (PGRs); as a cheap alternative to enhance plant growth and increase productivity. Application of plant growth regulators has been found very effective in improving quantity and quality of many crops [2]. Plant Growth Regulators (PGRs) have wide category of compounds that can enhance, inhibit or change plant morphological or physiological processes at very low concentrations. Thus, the use of PGRs has become an important element of the agrotechnical procedures for most cultivated crops [3]. The most studied PGRs include Abscisic Acid, Indole Acetic Acid, Cytokinin, Gibberellic Acid, Ethylene, Jasmonic Acid and Salicylic Acid [4]. Also, there are new, but chemically unrelated compounds with a similar hormone. Most of these chemical or natural substances, have not been studied for their effect on plants; especially vegetables and fruits that enter directly into the human daily diet such as tomatoes, which occupies the fourth rank in terms of worldwide production with approximately 5 million ha, as a harvested area produced 170.75 million tones according to FAO statistics' database [5].

Tomato is an important condiment in most diets and a very cheap source of vitamins and nutrients that are very good for the human body. It also protects the body against diseases [6]. This is primarily because these vitamins and beta-carotene work as antioxidants to neutralize harmful free radicals in the human blood [7]. In that regard, our research aims at improving plant performance, fruit set and yield of tomatoes by studying the effect of plant growth regulators (synthetic and natural) on tomato plants (Lycopersicon esculentum), using different new types (Magictone and Hemo bles as growth regulators) on Big Beef F1 tomato hybrid.

\section{Materials and methods}

Two different types of growth regulators were applied three times on tomato plants (Big Beef F1): Magictone active substances $(5 \ldots 12.5 \mathrm{~g} / \mathrm{kg}$ ) naphthalene acetic acid and naphthalene acetamide with applied doses (250, 500 and $700 \mathrm{ppm}) \mathrm{C}_{10} \mathrm{H}_{7} \mathrm{CH}_{2} \mathrm{CO}_{2} \mathrm{H}$, $\mathrm{C}_{12} \mathrm{H}_{11}$ NO. Hemo bles (250, 500 and 700 ppm): active substances Ener-850 / kg Humic Acid. All applied doses expressed in terms of active substances. Each type was applied three times with three replications (spraying on plants at 30 DAP, 60 DAP and 90 DAP). Soaked seeds were planted on trays, then after $30 \mathrm{DAP}$, tomato seedlings were transplanted on pots (20-inch diameter). Average day and night temperatures in greenhouses were $25^{\circ} \mathrm{C}$ and $18{ }^{\circ} \mathrm{C}$, this conforms within normal temperature ranges established for greenhouse. Collecting data: Ten plants from each replicate (3 replicates) were selected to measure the following parameters: Plant height (cm), Number of Leaves per Plant, Leaf Area Index (LAI) ( $\mathrm{m}^{2} /$ Plant), Chlorophyll content and Weight of Fruit (g). LAI was measured by (nondestructive method). Biochemical properties were evaluated in the fruit ripening stage to determine; dry matter which was calculated by weighing fruits before being 
put in the oven and after dried at $105^{\circ} \mathrm{C}$; Ascorbic acid (AA) was determined by the 2,6-dichlorophenolindophenol method [8]. Carotenoids and Nitrate were determined based on standards of the association of analytical communities [9]. Sugar-acid ratio (Maturity index) was calculated by dividing total soluble solid by the titratable acidity of the given sample under analysis as described by [10]. The results were analyzed using one-way analysis of variance (ANOVA) followed by Tukey's HSD test with $\alpha=0.05$ with the help of Co-stat program.

\section{Results and discussion}

Plant height (cm) of tomato plant was found to be significantly affected by spraying treatments with Hemo bles and Magictone in Fig.1. Results showed that spraying plants with Hemo bles 500 ppm showed the highest value of plant height at 30 and 60 days after transplanting (DAT), 700 ppm level showed the highest value of plant height at 90 days after transplanting, respectively, in the first season. In the second season, Spraying Hemo bles plants at 500 registered the highest value of plant height (85.8, 130.5 and 264.67 at 30, 60 and 90 days after transplanting (Fig. 1). Our results agree with [11], who reported that Humic Acid (Hemo bles) increased absorption of nutrients by plants and improved the permeability of membranes of root cells to tomato cultures. Also, [12-13] proved that Humic Acid had a positive effect on seed germination, seedling growth, root initiation, root growth, shoot development and the uptake of nutrient elements.

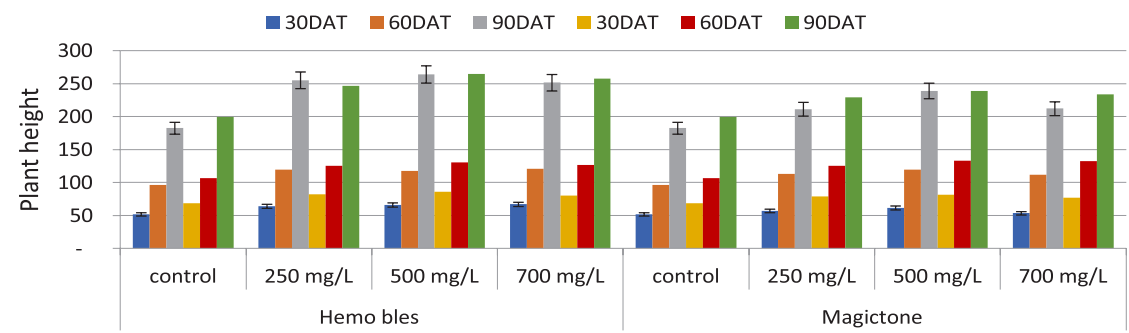

Fig. 1. Effect of growth regulators on plant height of tomato plants during the two seasons

Number of leaves: Number of leaves produced by tomato plants was found to be significantly affected by spraying treatments with Hemo bles and Magictone (Fig. 2). Results showed that spraying with Humic Acid (Hemo bles) 700 ppm recorded the highest value of number of leaves (16.67, 34.00 and 19.00, 37.33) at 30 and 60 days after transplanting during the two growing seasons. Spraying with $500 \mathrm{ppm}$ recorded the highest value of Number of leaves (45.60 and 45.00) at 90 days after transplanting during the two growing seasons. On the other hand, untreated control recorded the lowest value of number of leaves during the two growing seasons. Our results are consistent with those obtained by [14], who demonstrated that the number of leaves in tomatoes increased with the use of plant growth regulators. This may be attributed to the fact that plant growth regulators improved cellular nutrition and division with a significant elongation of the stem. The results also corroborate with the results of [15] who reported that the varieties affected the nature of the growth processes. 


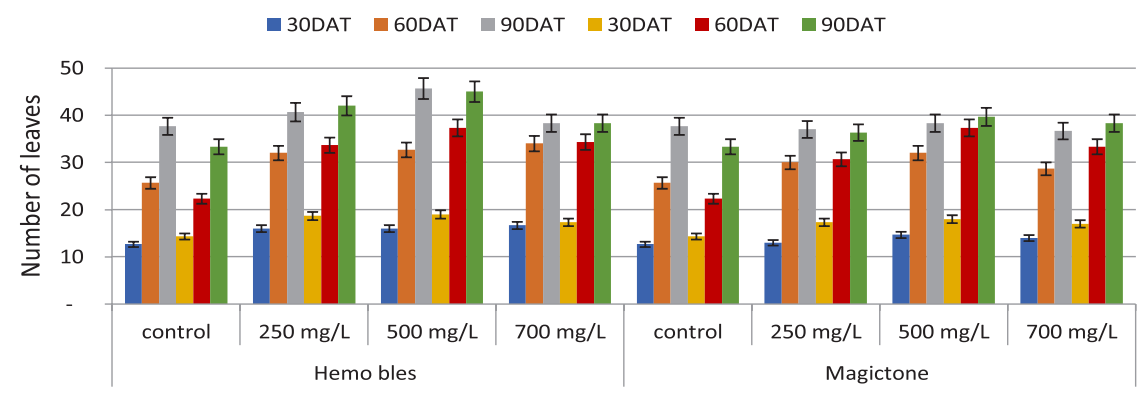

Fig. 2. Effect of growth regulators on leaf number of tomato plants during the two seasons

Stem diameter: The stem diameter of tomato plant was found to be significantly affected by spraying treatments with Hemo bles and Magictone (Fig. 3). Results showed that no significant differences were found between Humic Acid (Hemo bles) 700 ppm value of stem diameter $(1.10$ and $2.13 \mathrm{~cm}$ ) in the first season at 30 and 90 days after transplanting, but the planting sprayed with Humic Acid (Hemo bles) 500 ppm displayed the highest value of stem diameter $(1.37 \mathrm{~cm})$ in the first season at 60 days after transplanting followed by $500 \mathrm{ppm}$ level displayed the highest value of stem diameter (1.17, 1.57 and 1.90 $\mathrm{cm})$ at 30, 60 and 90 days after transplanting in the second season. On the other hand, untreated control recorded the lowest value of stem diameter during the two growing seasons. Similar results were obtained by [16-17].

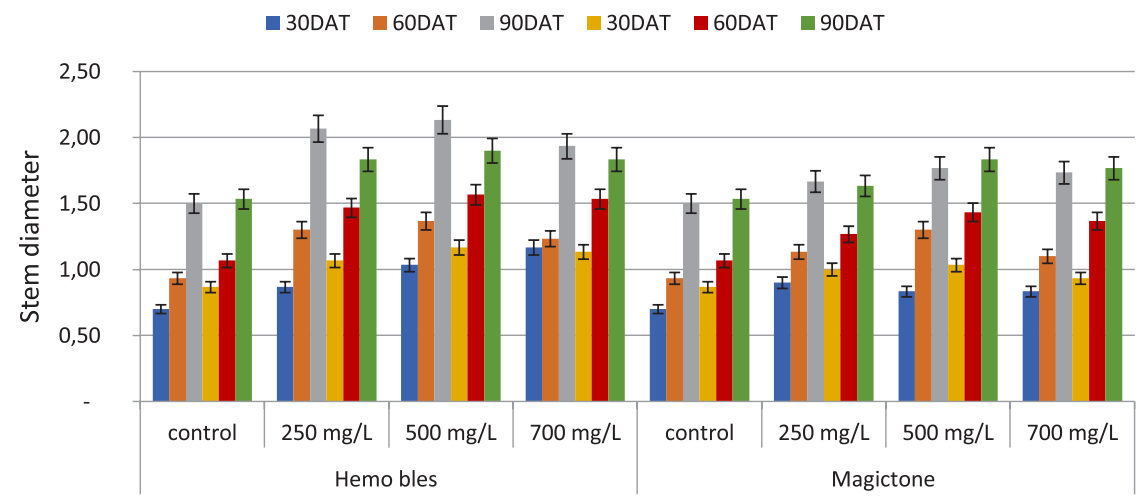

Fig. 3. Effect of growth regulators on stem diameter of tomato plants during the two seasons

Number of clusters produced by tomato plant was found to be significantly affected by spraying Hemo bles and Magictone treatments (Fig.4). Results showed that plants sprayed with $500 \mathrm{ppm}$ produced the highest value of number of clusters (4.33) (12.67) at 30 and 90 days, following $700 \mathrm{ppm}$ produced the highest value (10.60) at 60 after transplanting in the first season. $500 \mathrm{ppm}$ treatment produced the highest value of number of clusters (4.67, 12.33 and 15.60) at 30, 60 and 90 days after transplanting in the second season. On the other hand, untreated control registered the lowest value during the two growing seasons. 


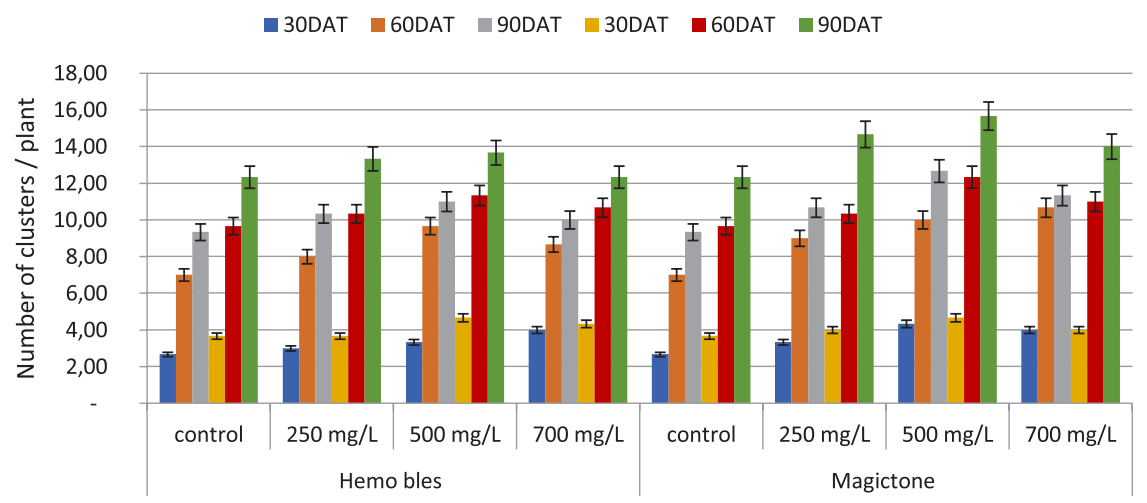

Fig. 4. Effect of growth regulators on Number of clusters of tomato plants during the two seasons

Leaf Area Index (LAI): Data obtained in Fig. 5 explain changes in leaf area measurements as a response of the application of different growth regulators to tomato plants at various times. At 90 DAP, applying Hemo bles and Magictone increased LAI comparing to the control, except (Hemo - 500) which was significant. The maximum area (200.87, 207.20 $\mathrm{cm}^{2}$ ) was obtained from Hemo - 500, while the minimum (156.80, $179.13 \mathrm{~cm}^{2}$ ) was in control during the two growing seasons. Obtained results are in agreement with those obtained by [16-17].

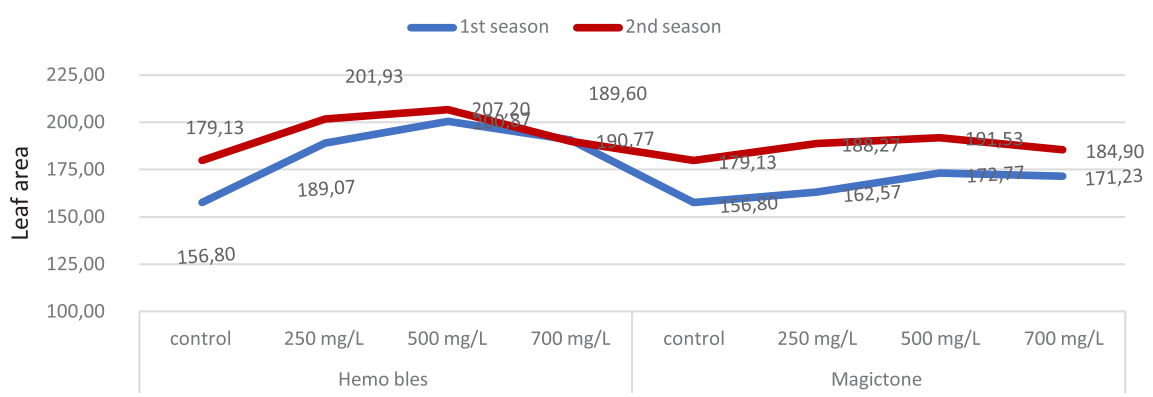

Fig. 5. Effect of growth regulators on leaf area index of tomato plants during the two seasons

Number of fruits: Fruits produced by tomato plant were found to be significantly affected by Hemo bles and Magictone treatments (Fig. 6). The maximum number of fruits (5, 48 and 62.00) (6.50, 43.89 and 64.60) were recorded from (Magictone - 500), while the minimum number of fruits per plant (1.60, 31.00 and 45) (3.6, 32.32 and 44) was recorded in control during two seasons. It might be due to that naphthalene acetic acid enhanced fruit setting in tomato plants. In respect of fruit set per plant in Kendras F1 it was found in agreement with the conclusions of [18]. 


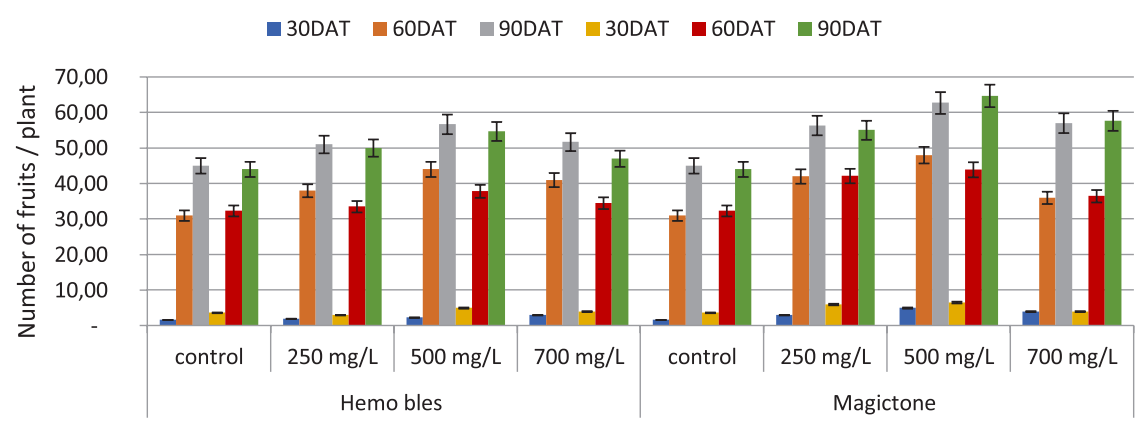

Fig. 6. Effect of growth regulators on Number of fruits of tomato plants during the two seasons

Chemical composition: Results of the chemical composition of tomato fruits affected by different doses of studied growth regulators are shown in Table 1 and 2. Dry matter ranges between 6.13, $6.1 \mathrm{~g} / 100 \mathrm{~g}$ in control's samples and 7.77, 7.67 g/100 $\mathrm{g}$ in the fruits which treated by Humic Acid (Hemo - 700). Applying Humic Acid enhanced dry matter contents (7.20...7.77 g/100 g) comparing to Magictone (6.30...6.60 g/100 g). TSS was significantly decreased by using spraying levels as compared with control fruits. Control treatment displayed the highest TSS (5.90 $\left.{ }^{\circ} \mathrm{Brix}\right)$ at 90 days after transplanting followed by Hemo-500 ppm (5.70 ${ }^{\circ}$ Brix) in the first season. The plants sprayed with Hemo-500 ppm recorded the highest TSS (6.0 ${ }^{\circ}$ Brix) at 90 days after transplanting followed by $0 \mathrm{ppm}\left(5.96^{\circ} \mathrm{Brix}\right)$ treatment in the second season. Dry matter ranges between 6.13, $6.10 \mathrm{~g} / 100 \mathrm{~g}$ in control's samples and 7.77, $7.67 \mathrm{~g} / 100 \mathrm{~g}$ in the fruits which treated by Humic Acid (Hemo - 700). Applying Humic Acid enhanced dry matter contents (7.20...7.77 g/100 g) comparing to Magictone (6.30...6.60 g/100 g). Dry matter ranges between $6.13,6.10 \mathrm{~g} / 100 \mathrm{~g}$ in control's samples and 7.77, 7.67 g/100 $\mathrm{g}$ in the fruits which treated by Humic Acid (Hemo - 700). Applying Humic Acid enhanced dry matter contents (7.2 ..7.77 g/100 g) comparing to Magictone (6.30...6.60 g/100 g).

Table 1

\section{Effect of Hemo bles And Magictone on chemical characters of Big Beef tomato cultivar (2017)}

\begin{tabular}{|c|c|c|c|c|c|c|}
\hline Treatments & $\begin{array}{l}\text { Dry matter, } \\
{\mathrm{g} 100 \mathrm{~g}^{-1}}^{-}\end{array}$ & TSS (Brix) & $\begin{array}{l}\text { Vitamin } C \\
\mathrm{mg} / 100 \mathrm{~g}\end{array}$ & $\begin{array}{l}\text { Carotenoids, } \\
\text { mg } 100 \mathrm{~g}^{-1}\end{array}$ & 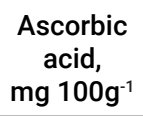 & $\begin{array}{l}\text { Chlorophyll } \\
\text { SPAD }\end{array}$ \\
\hline Control & $6.13 \mathrm{~d}$ & $5.93 \mathrm{a}$ & $18.28 \mathrm{c}$ & $3.05 \mathrm{c}$ & $19.73 \mathrm{~d}$ & $70.87 d$ \\
\hline Hemo-250 ppm & $7.27 \mathrm{~b}$ & $5.60 a b$ & $19.23 \mathrm{ab}$ & $4.71 \mathrm{a}$ & $25.20 \mathrm{bc}$ & $74.18 \mathrm{~b}$ \\
\hline Hemo-500 ppm & $7.63 \mathrm{a}$ & $5.70 \mathrm{a}$ & $19.83 \mathrm{a}$ & $4.86 \mathrm{a}$ & $26.90 \mathrm{~b}$ & $76.48 a b$ \\
\hline Hemo-700 ppm & $7.77 \mathrm{a}$ & $5.60 a b$ & $19.95 \mathrm{a}$ & $4.92 \mathrm{a}$ & $27.57 \mathrm{a}$ & $78.86 \mathrm{a}$ \\
\hline Magi-250 ppm & $6.33 c$ & $5.33 \mathrm{c}$ & $18.49 \mathrm{bc}$ & $4.12 \mathrm{~b}$ & $22.70 \mathrm{c}$ & $72.27 \mathrm{c}$ \\
\hline Magi-500 ppm & $6.60 \mathrm{bc}$ & $5.57 \mathrm{~b}$ & $19.10 \mathrm{~b}$ & $4.20 \mathrm{~b}$ & $22.77 \mathrm{c}$ & $75.75 b$ \\
\hline Magi-700 ppm & $6.37 c$ & $5.63 \mathrm{ab}$ & $19.15 b$ & $4.45 a b$ & $22.00 \mathrm{~cd}$ & $75.70 \mathrm{~b}$ \\
\hline
\end{tabular}


Effect of Hemo bles And Magictone on chemical characters of Big Beef tomato cultivar (2018)

\begin{tabular}{|c|c|c|c|c|c|c|}
\hline Treatments & $\begin{array}{l}\text { Dry matter, } \\
{\mathrm{g} 100 \mathrm{~g}^{-1}}^{-}\end{array}$ & $\begin{array}{c}\text { TSS } \\
\left({ }^{\circ} \text { Brix }\right)\end{array}$ & $\begin{array}{c}\text { Vitamin C, } \\
\mathrm{mg} / 100 \mathrm{~g}\end{array}$ & $\begin{array}{l}\text { Caroten- } \\
\text { Oids, } \\
\text { mg } 100 \mathrm{~g}^{-1}\end{array}$ & $\begin{array}{c}\text { Ascorbic acid, } \\
{\mathrm{mg} 100 \mathrm{~g}^{-1}}^{-}\end{array}$ & $\begin{array}{l}\text { Chlorophyll } \\
\text { SPAD }\end{array}$ \\
\hline Control & $6.10 \mathrm{~d}$ & $5.96 \mathrm{a}$ & $18.33 \mathrm{c}$ & $3.95 \mathrm{~d}$ & $20.27 d$ & $73.22 \mathrm{c}$ \\
\hline Hemo-250 ppm & $6.97 \mathrm{~b}$ & $5.63 \mathrm{c}$ & $18.48 \mathrm{bc}$ & $4.7 b$ & $25.20 \mathrm{~b}$ & $68.61 \mathrm{~d}$ \\
\hline Hemo-500 ppm & 7.67 a & $6.00 \mathrm{a}$ & $19.53 \mathrm{a}$ & $4.82 \mathrm{a}$ & $26.43 \mathrm{a}$ & 75.32 bc \\
\hline Hemo-700 ppm & $7.23 a b$ & $5.90 \mathrm{a}$ & $18.84 \mathrm{~b}$ & $4.92 \mathrm{a}$ & $26.43 \mathrm{a}$ & $73.37 \mathrm{c}$ \\
\hline Magi-250 ppm & $6.67 c$ & $5.40 \mathrm{~cd}$ & $18.35 \mathrm{c}$ & $4.14 \mathrm{c}$ & $22.57 \mathrm{bc}$ & $75.93 \mathrm{~b}$ \\
\hline Magi-500 ppm & $7.00 \mathrm{~b}$ & $5.93 \mathrm{a}$ & $19.54 \mathrm{a}$ & $4.23 \mathrm{c}$ & $23.93 \mathrm{c}$ & $78.81 a$ \\
\hline Magi-700 ppm & $6.97 \mathrm{~b}$ & $5.83 \mathrm{~b}$ & $19.07 \mathrm{~b}$ & $4.25 \mathrm{c}$ & $22.87 \mathrm{c}$ & $78.04 \mathrm{a}$ \\
\hline
\end{tabular}

Our results agree with [11], who reported that Humic Acid enhanced mineral nutrients absorption by plants and increased the permeability of membranes of root cells to tomato plants. Also, shoots and root weights were increased by $22 \%$ as a result of using Humic Acid in tomato plants [19]. TSS was significantly decreased by using spraying levels as compared with control fruits. Control treatment displayed the highest TSS (5.9 ${ }^{\circ}$ Brix) at 90 days after transplanting followed by Hemo-500 ppm (5.7 ${ }^{\circ} \mathrm{Brix}$ ) in the first season. The plants sprayed with Hemo-500 ppm recorded the highest TSS (6.0 ${ }^{\circ}$ Brix) at 90 days after transplanting followed by control treatment (5.96 $\left.{ }^{\circ} \mathrm{Brix}\right)$ in the second season. The obtained results are in agreement with those obtained by [20-22]. Also, [23] observed that the values commonly obtained for soluble solids of different cultivars of tomato fruit range from 4 to $6{ }^{\circ}$ Brix. Moreover, [24] noticed that the main soluble sugars in tomato fruit were glucose and fructose which made up $47 \%$ of the fruit dry matter. Hemo - 700 gave the highest increased contents of Vitamin C (Ascorbic acid) and Carotene in tomato fruits in the first season. In the second season, Magi — 500 gave the highest increased contents of Vitamin C (Ascorbic acid) in tomato fruits from. Comparing to Hemo-700, the highest levels of Ascorbic Acid (27.57 mg 100g-1) and Chlorophyll (78.86) in the first season were observed when Magi - 500 was applied, while the samples treated by Magictone gave the increased contents of Chlorophyll in tomato fruits in the second season.

\section{Conclusion}

Thus, it can be noted that the studied growth regulators had a positive effect on the growth processes of Big Beef tomato plants: morphometric parameters of plants and influenced the formation of generative organs of the plant. The best indices for tomato yield were observed after treating plants with growth regulators - Magictone. Therefore, we recommend using the compound to increase the yield at an acceptable economic rate. 


\section{References}

1. Kaloo. Tomato: Lycopesicon esculentum Miller. New Delhi: Allied publishers private. ltd; 1986.

2. Singh SK, Nidhika T, Yamini S. Plant growth regulators in fruit and vegetable crops. International Journal of Agricultural Sciences. 2013; 9(1):433-437.

3. Kader AA. Flavor quality of fruits and vegetables. Journal of the Science of Food and Agriculture. 2008; 88(11):1863-1868. doi: 10.1002/jsfa.3293

4. Santner A, Calderon-Villalobos L, Estelle M. Plant hormones are versatile chemical regulators of plant growth. Nat Chem Biol. 2009; 5:301-307. doi: 10.1038/nchembio.165

5. FAO 2017. Available from: http://www.fao.org/faostat/en/\#data/QC14/07/2017.

6. Taylor IB. Biosystematics of the tomato. In: Atherton JG, Rudich J. (eds.) The tomato crop: A scientific basis for improvement. New York: Chapman and Hill; 1986. p. 1-34.

7. Bhowmik D, Kumar KS, Paswan S, Srivastava S. Tomato-A Natural Medicine and Its Health Benefits. Journal of Pharmacognosy and Phytochemistry. 2012; 1(1): 33-43.

8. AOAC. Official methods of analysis of the Association of Official Analytical Chemists. 15th ed. Washington: Association of Official Analytical Chemists; 1990.

9. AOAC. Official methods of analysis of AOAC International. 18th ed. Gaithersburg: AOAC International; 2006.

10. Mohammed M, Wilson LA, Gomes PL. Postharvest sensory and physiochemical attributes of processing and non-processing tomato cultivars. J Food Qual. 1999; 22(2):167-182. doi: 10.1111/j.1745-4557.1999. tb00549.x

11. Valdrighi MM, Pera A, Agnolucci M, Frassinetti S, Lunardi D, Vallini G. Effects of compost-derived humic acids on vegetable biomass production and microbial growth within a plant (Cichorium intybus)-soil system: a comparative study. Agric Eco and Envir. 1996; 58(2-3):133-144. doi: 10.1016/0167-8809(96)01031-6

12. Chen Y, Aviad T. Effects of humic substances on plant growth. In: MacCarthy P, Clapp CE, Malcolm RL, Bloom PR. (eds.) Humic Substances in Soil and Crop Sciences: Selected Readings. Madison, USA: Soil Science Society of America; 1990. p. 161-186. doi: 10.2136/1990.humicsubstances.c7

13. Varanini Z, Pinton R. Humic substances and plant nutrition. In: Behnke HD, Lüttge U, Esser K, Kadereit JW, Runge M. (eds.) Progress in Botany. Vol. 56. Berlin: Springer; 1995. p. 97-117. doi: 10.1007/978-3-64279249-6_5

14. Gabal GM, Oben G, Gardella R. Effect of GA on morph physiological characters and yield of kidney beans (Phaseiolus valgaris). Journal of Agronomy and Crop Science. 1999; 160(2):91-101.

15. Ibrahim K, Amans A, Abubakar IU. Growth indices and yield of Tomato (Lycopesicon esculentum karest) varieties as influenced by crop spacing at samaru. In: Proceedings of the 18th HORTSON Conference, IAR/ABU Zaria, May 28-June 1, 2000. Zaria: Ahmadu Bello University; 2000. p. 40-47.

16. Gupta PK, Gupta AK. Efficacy of plant growth regulators (IAA and NAA) and micronutrient mixtures on growth, flowering, fruiting and shelf life of tomato (Lycopersicon esculentum, Mill.). Bioved. 2000; 11(12):25-29.

17. Rahul S, Sant AK, Lal S. Effect of plant growth regulators and micro-nutrient mixtures on growth and yield of tomato (Lycopersicon esculentum Mill.). Bioved. 2005; 16:101-105.

18. Akhtar N, Bhuiyan AH, Quadir A, Mondal F. Effect of NAA on the yield and quality of summer tomato. Annals of Bangladesh Agriculture. 1996; 6(1):67-70.

19. Yildirim E. Foliar and soil fertilization of humic acid affect productivity and quality of tomato. Acta Agriculturae Scandinavica, Section B - Soil \& Plant Science. 2007; 57(2):182-186. doi: 10.1080/09064710600813107

20. Adam SM, Abdalla AM, Abou-Hadid AF. Effect of shading on the growth and productivity of some tomato cultivars in the summer season. Egyptian Journal of Horticulture. 2002; 29(2):271-280.

21. El-Aidy F, Moustfa S and El-Afry, M. Influence of shad on growth and yield of tomatoes cultivated during the summer season in Egypt. Tanta University Journal of Agricultural Research (Egypt). 1983; 9(1):123-128.

22. El-Gizawy AM, Abdallah MMF, Gomaa HM, Mohamed SS. Effect of different shading levels on tomato plants. 2. Yield and fruit quality. Acta Hort. 1993; 323:349-354. doi: 10.17660/ActaHortic.1993.323.32

23. Cramer M, Oberholzer J, Combrink N. The effect of supplementation of root zone dissolved inorganic carbon on fruit yield and quality of tomatoes (cv 'Daniella') grown with salinity. Scientia Horticulturae. 2001; 89(4):269-289. doi: 10.1016/S0304-4238(00)00243-0

24. Suarez MH. Rodriguez EMR, Romero CD. Chemical composition of tomato (Lycopersicon esculentum) from Tenerife, the Canary Islands. Food Chemistry, 2008; 106(3):1046-1056. doi: 10.1016/j.foodchem.2007.07.025 


\begin{abstract}
About authors:
Suliman Ahmad Ali — PhD student, National Research Centre, 33 El Behouth St., Dokki, Giza, Egypt, 12622; Kazan State Agrarian University, 65, K. Marks st., Kazan, Republic of Tatarstan, Russian Federation, 420015; e-mail: a_elsagheer2006@yahoo.com
\end{abstract}

Abramov Alexandr Gennadevich - Candidate of Agricultural Sciences, Associate Professor, Department of plant and vegetable production, Kazan State Agrarian University, 65, K. Marx st., Kazan, Republic of Tatarstan, Russian Federation, 420015; e-mail: gal4959@yandex.ru.

Shalamova Anna Alekseevna - Candidate of Agricultural Sciences, senior researcher, Department of plant and vegetable production, Kazan State Agrarian University, 65, K. Marx st., Kazan, Republic of Tatarstan, Russian Federation, 420015; e-mail: a6685025a@yandex.ru.

Badran Antar Mahmoud — PhD student, Agroengineering Department, Agrarian and Technological Institute, Peoples’ Friendship University of Russia, 8/2 Miklukho-Maklaya st., Moscow, Russian Federation, 117198; Desert Research Center, 1 Mathaf El-Mataria st., Matariya, Cairo, Egypt, 11753; e-mail: dr_antar_mahmoud@ yahoo.com

\title{
Влияние гуминовой и нафталинуксусной кислоты на вегетативный рост и качество плодов томатов Lycopersicon esculentum
}

\author{
А.А. Сулиман ${ }^{1,2 *}$ А.Г. Абрамов², А.А. Шаламова², А.М. Бадран ${ }^{3,4}$ \\ ${ }^{1}$ Национальный исследовательский центр, г. Гиза, Египет \\ ${ }^{2}$ Казанский государственный аграрный университет, \\ 2. Казань, Республика Татарстан, Российская Федерация

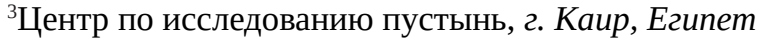 \\ ${ }^{4}$ Российский университет дружбы народов, г. Москва, Российская Федерация \\ *a_elsagheer2006@yahoo.com
}

\begin{abstract}
Аннотация. С целью повышения продуктивности исследовали влияние регуляторов роста на растения томата Lycopersicon esculentum. Изучено влияние регуляторов роста Hemo bles (с содержанием гуминовой кислоты 850 г/кг) в концентрации 250, 500 и 700 ppm и Magictone (с содержанием нафталинуксусной кислоты и нафталин ацетамида 5...12,5 г/кг) в концентрации 250, 500 и 700 ppm на рост и физиологические параметры растений томата сорта Биг Биф F1. Опрыскивание растений регуляторами роста Hemo bles и Magictone проводили три раза (через 30, 60 и 90 дней после посадки). Полученные результаты показали, что применение препарата Ener-850 с гуминовой кислотой в течение двух сезонов оказало наилучшее влияние на показатели роста растений: высоту побегов (264,6 см), количество листьев на 1 растении (45 шт.), диаметр стебля (1,9 см), массу плодов (137 г). Использование препарата Magictone способствовало образованию большого числа цветков $(48,1)$, плодов $(35,1)$ и соцветий $(13,6)$ на одном растении. Гуминовая кислота также оказывала положительное влияние на качество плодов томата, увеличивая долю сухих веществ (75,1 г) надземной массы растений, в результате чего возрастало количество аскорбиновой кислоты, витамина С и каротиноидов (4,82 мг/100 г). Результаты были проанализированы с использованием однофакторного дисперсионного анализа (ANOVA) с последующим HSD-тестом Тьюки с $\alpha=0,05$ с помощью программы MINITAB (v. 19.0).

Ключевые слова: томат, гуминовая кислота, нафталинуксусная кислота, регуляторы роста растений, аскорбиновая кислота
\end{abstract}




\section{История статьи:}

Поступила в редакцию: 18 декабря 2019 г. Принята к публикации: 13 января 2020 г.

\section{Для цитирования:}

Suliman A.A., Abramov A.G., Shalamova A.A., Badran A.M. Effect of humic acid and naphthalene acetic acid on vegetative growth and fruit quality of tomato plants Lycopersicon esculentum // Вестник Российского университета дружбы народов. Серия: Агрономия и животноводство. 2020. Т. 15. № 1. С. 30 - 39. doi: 10.22363/2312-797X-2020-15-1-30-39

\section{Об авторах:}

Сулиман Ахмад Али - аспирант кафедры растениеводства и плодоовощеводства, Казанский государственный аграрный университет, Российская Федерация, 420015, Республика Татарстан, г. Казань, ул. К. Маркса, д. 65; Национальный исследовательский центр, Египет, 12622, г. Гиза, Докки, ул. Эль-Бехут, д.33; e-mail: a_elsagheer2006@yahoo.com

Абрамов Александр Геннадьевич — кандидат сельскохозяйственных наук, доцент кафедры растениеводства и плодоовощеводства, Казанский государственный аграрный университет, Российская Федерация, 420015, Республика Татарстан, г. Казань, ул. К. Маркса, д. 65; e-mail: gal4959@yandex.ru

Шаламова Анна Алексеевна - кандидат сельскохозяйственных наук, старший научный сотрудник кафедры растениеводства и плодоовощеводства, Казанский государственный аграрный университет, Российская Федерация, 420015, Республика Татарстан, г. Казань, ул. К. Маркса, д. 65; e-mail: a6685025a@yandex.ru

Бадран Антар Махмуд - аспирант агроинженерного департамента, Аграрно-технологический институт, Российский университет дружбы народов, Российская Федерация, 117198, г. Москва, ул. Миклухо-Маклая, д. 8/2; Центр по исследованию пустынь, Египет, 11753, г. Каир, Матария, ул. Матаф эль-Матария, д. 1; e-mail: dr_antar_mahmoud@yahoo.com 